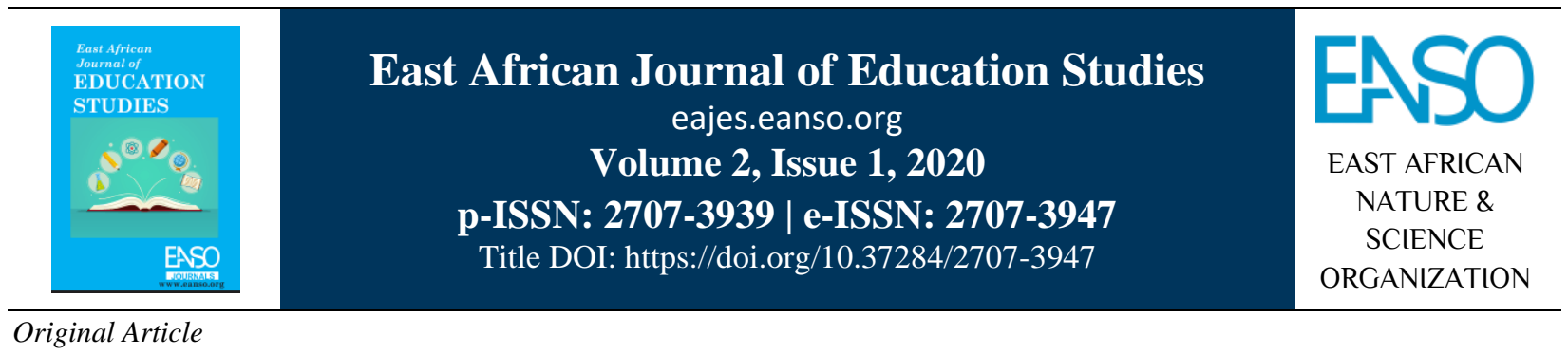

\title{
Teachers' Computer Literacy in Selected Public Primary Schools in Ainamoi Sub-County in Kericho County, Kenya
}

\author{
Beatrice Chebet Ngeno*, Dr. Hellen C. Sang \& Dr. Carolyn Chemosit \\ ${ }^{1}$ University of Kabianga, P. O. Box 2030 - 20200, Kericho, Kenya \\ * Author for Correspondence email: ngenoc.beatrice@ gmail.com
}

Article DOI: https://doi.org/10.37284/eajes.2.1.111

\section{Article history:}

Received: 23 Sep 2019

Accepted: 07 Oct 2019

Published: 30 Jan 2020

Keywords:

Computer Literacy,

Public Primary,

Computer Competence,

Kericho County,

Ainamoi.

\section{ABSTRACT}

The practice of integrating education with computers has been used worldwide because of the emerging education global trends. Computer literacy in teachers plays an important role in the integration of technology in education, which favours the Kenyan education system. This study set out to determine the teacher computer literacy level in public primary schools Ainamoi Sub-County, Kericho. A descriptive survey design was used involving 21 headteachers, 42 lower primary teachers, one ICT Expert, and CASO officer. Data were collected using structured interviews, questionnaires, and checklist observation. Purposive, simple random sampling and stratified sampling were used to sample the respondents. Data were presented in tables and percentages. The findings revealed that computer teacher training that was done in May 2015 did not cater for all the teachers in the field. This is because headteachers and only two lower primary teachers were trained from each school. It was also founded that teachers who graduated from teacher training colleges from 2009 were computer literate out of all the teachers employed by the Teachers Service Commission (TSC) after 2006. There is a need for the government to arrange the seminars and in-service programs to cater to those teachers who are already in the field but are computer noncompliant. Teachers should be ready to embrace the new technology and integrate it into teaching and learning. Teachers should have more exposure to computers and ICT facilities to enhance their computer competency. A digital computer content guide should be developed by the Kenya Institute of Curriculum Development to enhance consistent computer knowledge. Besides, teacher training colleges should provide KNEC examinable computer courses. 


\section{APA CITATION}

Ngeno, B., Sang, H., \& Chemosit, C. (2020). Teacher Computer Literacy in Selected Public Primary Schools in Ainamoi SubCounty in Kericho County, Kenya. East African Journal of Education Studies, 2(1), 1-7. https://doi.org/10.37284/eajes.2.1.111

\section{CHICAGO CITATION}

Ngeno, Beatrice, Hellen Sang, and Carolyn Chemosit. 2020. "Teacher Computer Literacy in Selected Public Primary Schools in Ainamoi Sub-County in Kericho County, Kenya". East African Journal of Education Studies 2 (1). https://doi.org/10.37284/eajes.2.1.111.

\section{HARVARD CITATION}

Ngeno, B., Sang, H. and Chemosit, C. (2020) "Teacher Computer Literacy in Selected Public Primary Schools in Ainamoi SubCounty in Kericho County, Kenya”, East African Journal of Education Studies, 2(1). doi: 10.37284/eajes.2.1.111.

\section{IEEE CITATION}

B. Ngeno, H. Sang, and C. Chemosit, "Teacher Computer Literacy in Selected Public Primary Schools in Ainamoi Sub-County in Kericho County, Kenya”, EAJES, vol. 2, no. 1, Jan. 2020.

\section{MLA CITATION}

Ngeno, B., H. Sang, and C. Chemosit. "Teacher Computer Literacy in Selected Public Primary Schools in Ainamoi Sub-County in Kericho County, Kenya”. East African Journal of Education Studies, Vol. 2, no. 1, Jan. 2020, doi:10.37284/eajes.2.1.111.

\section{INTRODUCTION}

Education plays a special and important role in the scientific, cultural, economic, and social development of the entire nation. Primary education is considered the basic foundation in a child's life hence acts as a bridge of knowledge across different aspects of life. An increased inclination characterized by global competition in the education sector has spurred computer integration in education systems. Kamal \& Qureshi (2009) noted that with the introduction of information technology, there have been computer knowledge advances in education systems. The education world face has changed because computer use has been integrated into all levels of learning and sectors. There is stiff competition for knowledge acquisition worldwide; World Bank (1995) stated that nations have a need for technology integration so as to meet the standards of living and the set national goals. Therefore, the World Bank took an initiative to support countries financially to improve the education systems.

Das, Sarkar \& Ray (2012) noted that the Indian government made important progress in achieving computer integration in education in public primary schools with a policy framework focused on initiatives to achieve goals. The computers in each school are targeted in making opportunities for administrators and learners in developing skills at the school level. He further noted that most headteachers and teachers use computers in their teaching and learning in public primary schools in developed countries. The untrained teachers were taken for in-service courses related to computer use.

The study was done in Rwanda by Minecofin (2007) on striving to achieve the computer literacy of teachers pointed out that the Kigali Institute of Education developed programs to train computer illiterate teachers to suit the new educational trends. A report by the Ministry of Education of Rwanda (2010) stressed that education professionals should be provided with opportunities to use computers so as to adapt to prevailing technological trends. This effort improves the effectiveness of teaching and learning because it exposes the learner to interactive computer-based learning and new educational trends. This also encouraged and motivated learners to participate in schools. A study by Nepad-E (2007) in Kenya revealed that school administrations attempted to set the physical infrastructure that supports the use of computers in school, but it was not supported. This was due to the lack of computers, poor computer literacy levels among teachers, high personnel to operate, expensive computers and a lack of electricity in some schools. It was further noted that the teachers feared that they would be useless if computers are integrated into teaching and learning in class (Nepad-E, 2007). Therefore, the Kenyan government needs to improve the teacher trainings to embrace technology. Little has been done to understand the computer literacy amongst teachers and how it impacts on teaching and learning. This 
aimed to determine the computer literacy level among public primary school teachers in the Ainamoi sub-county, Kericho County.

The Kenyan Government introduced the ICT policy in 2006 as the basic computer learning in teachers' training colleges and was non-examinable by KNEC (Kenya National Examination Council). Due to the global education trends, the government needed all the teachers to be computer compliant in terms of computer competence to enable them to integrate the technology in teaching and learning, accessing Teachers Service Commission online services, appraisal reports, and online registration of candidates for examinations. Therefore, there was a need to train teachers to use computers in their teaching and learning. The study done by the World Bank (2002) proved that the use of computers is effective in daily work; it also gives a wide range of options in using a computer in the teaching and learning process. Studies done in India and Rwanda have shown successful and appropriate teacher training and computer integration. This study sought to determine the teacher computer literacy in selected public primary schools in Ainamoi Sub-County, Kericho County in Kenya.

\section{LITERATURE REVIEW}

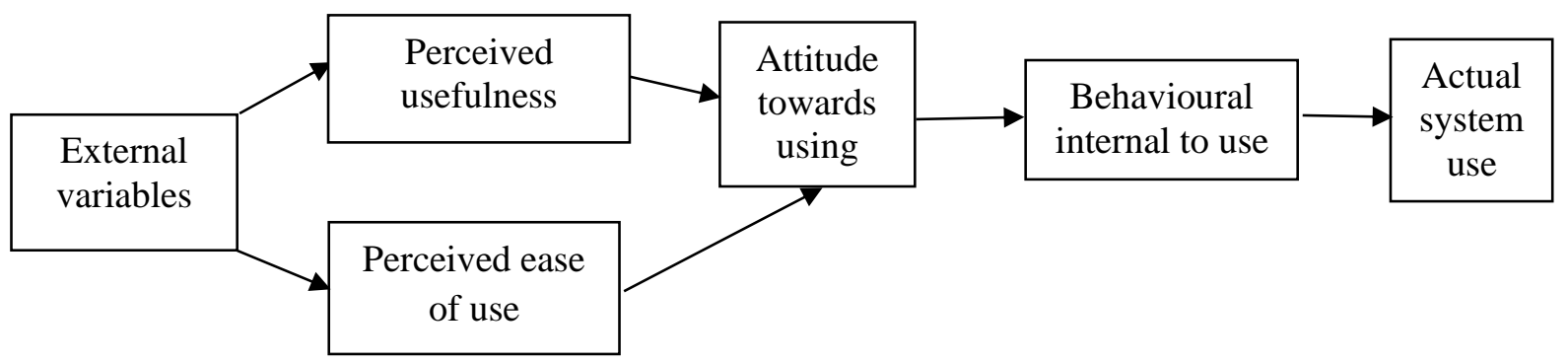

Technology Acceptance Model (TAM) by Davies (1989) was adopted. The theoretical framework of Davis (1989) which has been globally used to explain the understanding of an information system. The model is reliable in this study because it has two factors that are perceived ease and perceived usefulness to the user using a specific application system to promote his/her specific life performance. Perceived ease is the degree that a user expects an application to be free of effort while the perceived usefulness is the use and appropriateness as expected by an end-user. The two factors are affected by other variables such as skills, social factors like language, facilitating conditions, and political conditions. These factors contribute to the attitude of the user as they use the information system of the application. This translates into behavioural intention as a measure of appropriateness to apply the system.

A study done in Turkey by Sabzian, Gilakjani \& Sodouri (2013) revealed that the use of computers and related technologies was not a routine of teaching and learning. Most of the teachers lacked the computer literacy background to build technology and skills and were not using computers in their teaching and learning. Ekwueme's (2007) study on ICT pedagogical relations to teaching and learning noted that teachers access the internet without any assistance and the computer educational applications are low and minimal. He added that only a few science teachers are computer literate. A study done in Bondo in Kenya by Isaiah (2013) on the headteacher preparedness on the use of ICT found that they were few computer literate headteachers and teachers. The study further added that $75 \%$ of headteachers were not computer compliant, while $25 \%$ of computer compliant were insufficient depending on their administrative tasks.

\section{METHODOLOGY}

This study adopted a descriptive research methodology. According to Kothari (2004), the descriptive survey investigating facts and inquiries of different kinds from the respondents where the researchers have minimal or no influence on their responses. This design explores the relationships of variables in their natural settings as they occur. The use of a descriptive survey is useful for educational fact-finding because they provide a great deal of 
information (Kombo \& Tromp, 2006). Questionnaires, interviews and observation checklist were used to collect data. It gave the school headteachers and teachers enough time in which they gave a well-thought answer.

The Ainamoi sub-County schools have four administrative zones, namely: Kapsoit, Kapsaos, municipality, and Ainamoi zone. The sub-county is administered by Sub-county Assurance and Standard Officer (SCASO). Kericho Teachers Training College is located in Ainamoi Sub County hence a suitable study; the ICT expert used in the study was drawn there. According to the Ainamoi Sub-County education report (2017), there are 32 and 68 registered private and public primary schools respectively in the sub-county. The private primary schools were excluded from the study as the focus was mainly on the public primary schools, where the government has a stronger influence in infrastructural development. One headteacher and two lower primary teachers were selected to participate in the study while pupils did not participate. One SCASO officer and one ICT expert from Kericho teachers' college were interviewed respectively. Purposive sampling was done since there was only one teacher training college and one SCASO Officer in the study area.
The study utilized self-administered questionnaires, which were both open and closed-ended and were administered to 21 headteachers and 45 teachers. Sampling was done using stratified random sampling. Checklist observation was also used to counter check what was expected and the available information. An interview schedule was also involved in SCASO and the ICT expert.

The validity of measuring instruments is the extent to which it is supposed to measure. Content validity was used in the study. The test-retest of the instrument was administered for its reliability. Two schools involved in Piloting were done in a different county, which was Bureti Sub County.

Questionnaire data were checked for completeness, organized and analysed using the Statistical Package for Social Sciences (SPSS) version 17.0. Data were presented in percentages, mean and frequencies of respondents.

\section{RESULTS AND DISCUSSION}

The study review headteachers as well as teachers' computer literacy where the following results were achieved.

\section{Table 1: Computer Literacy Level}

\begin{tabular}{lll}
\hline Computer training & Yes (n, \%) & No (n, \%) \\
\hline Have attended a computer training course (Headteacher) & $7(33.34 \%)$ & $14(66.66 \%)$ \\
Have attended a computer training course (Teacher) & $5(11.60 \%)$ & $37(88.09 \%$ \\
Have basic knowledge (Headteacher) & $21(100 \%)$ & - \\
Basic knowledge (Teacher) & $20(47.62 \%)$ & $22(52.38 \%)$ \\
Have attended a seminar (Headteacher) & $14(66.67 \%)$ & $7(33.33 \%)$ \\
Attended seminar (Teacher) & $8(19 \%)$ & $34(81 \%)$ \\
Have attended primary ICT integration (Headteacher) & $18(85.71 \%)$ & $3(14.85 \%)$ \\
Primary ICT integration (Teacher) & $16(39 \%)$ & $26(61 \%)$ \\
Have done private training (Headteacher) & $8(38.09 \%)$ & $13(61.90 \%)$ \\
Private training (Teacher) & $18(43 \%)$ & $24(57 \%)$ \\
\hline
\end{tabular}

The finding indicated from table 1 showed that 7 (33.34\%) headteachers from the sampled schools attended computer training courses compared to 14 $(66.66 \%)$ who did not. This indicated that the majority of the headteachers were not computer course. Majority of the teacher also had not attended any computer course represented by 37 $(88.90 \%)$. Despite, the majority of headteacher not able to attend any computer course, all the headteachers had basic computer knowledge, while but only $20(47.62 \%)$ teachers had basic computer literacy. Fourteen $(66.67 \%)$ headteachers noted often attended computer-related seminars while 8 (19\%) teachers did not. This means that most of the headteacher acquired knowledge through seminars rather than through course training. Primary ICT 
integration, $18(85.71 \%)$ headteachers and 16 (39\%) teachers claimed to adopt them in their teaching and learning. For private computer training, 8 (38.09\%) headteachers noted often attended while only 18 (43\%) teachers. The findings of the computer training courses and seminars attended by teachers indicated that the headteachers have been trained in computer use more than teachers. This was due to the computer compliance course, which was done in May 2015 indicated that all headteachers were trained and one lower primary teacher attended the training. The computer training was meant for primary ICT integration. A few teachers underwent private training.

Table 2: Headteacher and Teacher Literacy in Computer Use

\begin{tabular}{lllll}
\hline Statement & & Proficiency & $\begin{array}{l}\text { Minimal } \\
\text { knowledge }\end{array}$ & $\begin{array}{l}\text { No } \\
\text { knowledge }\end{array}$ \\
\hline Use the excel program to write a class list & Headteacher & $18(85.71)$ & $3(14.28)$ & - \\
& Teacher & $20(47.62)$ & $8(19.04)$ & $12(33.33)$ \\
Use an existing spreadsheet to enter data. & Headteacher & $16(76.20)$ & $5(23.90)$ & \\
& Teacher & $18(42.85)$ & $9(21.42)$ & $17(35.71)$ \\
Prepare a power point presentation & Headteacher & $7(33.4)$ & $8(38.1)$ & $6(28.57)$ \\
& Teacher & $6(14.28)$ & $10(23.80)$ & $22(52.38)$ \\
\hline
\end{tabular}

Table 2 indicated the headteacher and teachers' literacy in computer use. Only 3(14.28\%) headteachers had minimal knowledge in computer use of Ms. Excel to create class lists while 18 $(85.71 \%)$ were proficient. MS Excel is applied by the majority of the headteacher more than the teacher since twenty teachers noted to have proficient computer literacy skills in the use of Ms Excel to create class lists while only 8 had minimal knowledge. Sixteen headteachers were proficient in entering data in the existing spreadsheet, while $23.9 \%$ had minimal knowledge. Out of the 42 teachers, only $42.85 \%$ were proficient using a spreadsheet to enter data, $21.42 \%$ had minimal knowledge while $35.71 \%$ had no knowledge. The spreadsheet also had more headteachers who were proficient in using for data recording than teachers. Regarding the preparation of PowerPoint presentations, $14.28 \%$ of the headteachers claimed to be proficient, $38.10 \%$ minimal knowledge while $28.56 \%$ had no knowledge. Out of the 42 teachers, 6 and 8 claimed to have proficient and minimal knowledge in the use of PowerPoint presentations respectively, while $52.38 \%$ had no knowledge.

Table 3: Headteacher and teacher usage of ICT

\begin{tabular}{lllll}
\hline & Minimum & Maximum & Mean & Std. Deviation \\
\hline Comp_demonstrate (HT) & 1 & 4 & 1.71 & .717 \\
Comp_demonstrate (T) & 1 & 2 & 1.24 & .431 \\
Comp_instruction (HT) & 1 & 4 & 1.71 & .717 \\
Comp_instruction (T) & 1 & 3 & 1.26 & .497 \\
Internet_notes (HT) & 1 & 4 & 3.05 & 1.024 \\
Internet_notes (T) & 1 & 4 & 2.38 & 1.324 \\
Internet_teaching (HT) & 1 & 4 & 1.71 & .784 \\
Internet_teaching (T) & 1 & 3 & 1.24 & .484 \\
Word_exams (HT) & 1 & 4 & 2.43 & 1.326 \\
Word_exams (T) & 1 & 4 & 1.79 & 1.220 \\
Word_minutes (HT) & 1 & 4 & 3.19 & .928 \\
Word_minutes (T) & 1 & 4 & 1.86 & 1.072 \\
Excel_exam (HT) & 2 & 4 & 3.29 & .784 \\
Excel_exam (T) & 1 & 4 & 2.79 & .871 \\
\hline
\end{tabular}


Table 4.3 indicated that headteachers were more knowledgeable and high utilized the ICT than the teachers with leading in all categories of ICT integration. The headteacher mostly utilized area included excel for examination analysis and entering marks, preparation of minutes and internet notes in that respective order. It was also found that the computer was rarely used by both teacher and headteacher in instruction and demonstration as well as in internet teaching.

The low mean amongst the variable indicates a low literacy level on computer use in teaching and learning among the teachers in public primary schools in Ainamoi Sub County. The demonstration had the least mean of all (1.33), meaning that the teacher has the least know-how in computer use more so in demonstrating the concept in class. They are more literate when it comes to using computers in setting to exams.

From the above findings, the headteachers are more computer literate than the teachers; this was enhanced through the primary ICT integration, which was done in May 2015 where all the headteachers from the public primary school and one lower primary school teacher were trained. Since on lower teacher was selected from every school, the rest of the lower teacher did not attend the primary ICT training. This is in contrast with a study done by Oulo (2013) in Bondo County which revealed that the training levels of headteachers in the use of ICT in public primary schools were low. All the Headteachers had attended a computer training courses and on computer use. Teachers who had a basic knowledge of computer use were few. The findings on the computer training courses and seminars attended by teachers indicate that the headteachers have been trained in computer use more than teachers. This was due to the computer compliance course which was done in May 2015, indicating that all headteachers were trained and one lower primary teacher attended the training. The computer training was meant for primary ICT integration.

The ICT expert gave the following programs that are offered in teachers training college: MS Excel, MS Word, MS Excess, PowerPoint program, Internet programs, and Printing. The ICT Expert also pointed out that the programs relevant to teaching and learning in public primary school Simulation programs were used to animate difficult concepts. Computer-aided instructions (CAI/CAD/CAT) normally use to present theoretical concepts. The respondent further noted that all the student teachers were trained since 2006 though KNEC did not examine it since the computers were not integrated with its usage in the primary schools. The student teachers were not serious in integrating computers in teaching and learning.

The SCASO officer noted that with the global educational trends, it was very important to integrate computers in teaching and learning processes. During teachers' recruitment, they don't focus so much on computer literacy, but basically, they have employed those teachers who have graduated from the teachers' college up to the year 2009. He further added that for those who were already in the field, the government organized training for ICT primary integration program seminar, which was done in May 2015. One lower primary teacher and headteacher was selected from every school.

Few teachers had trained in computer usage because they did not rely on computers to accomplish their teaching and learning; most teachers used their traditional way of teaching and learning. The strategies put in place to enhance the preparedness of teachers in the use of computers in public primary schools were through proposal writing by teachers to the government and NGOs to organize capacity building workshops in the use of computers. This was a positive indication on the way forward for computer integration in teaching and learning as we embrace new technology in the 21 st century.

\section{CONCLUSION AND RECOMMENDATIONS}

The researchers concluded that computer integration is low due to the lack of education for both headteacher and teachers. Most of the knowledge acquired was from seminars and workshops with headteacher been able to access the seminars as compared to teachers. It was also found that most headteachers used computer excel, spreadsheets and PowerPoint than teachers. This assists the headteacher to do excel exam analysis, 
preparation of minutes and internet notes. Teachers followed closely in the utilization of ICT in the same area of use. The computer was not utilized for demonstration, instruction nor teaching by both headteachers and teachers.

In light of the research findings, the researcher wishes to recommend that the government should arrange the in-service programs to cater for those teachers who are already in the field and not computer compliant. Teachers should be ready to embrace the new technology of computer integration in teaching and learning. Teachers should have more exposure to computers and ICT facilities to help in capacity building. The Ministry of Education should develop a policy of curriculum digital content guide, which will enable the teacher to integrate computers successful in teaching and learning. Teachers to be provided with professional opportunities in areas of computer technology through regular capacity building courses, workshops, and seminars. Teacher training institutions (universities and other Teacher Training Colleges) should evaluate how teacher trainees who are future teachers could be prepared to be computer literate and make computer courses to be KNEC examinable.

\section{REFERENCES}

Das, M. C., Sarkar, B., \& Ray, S. (2012). A framework to measure relative performance of Indian technical institutions using integrated fuzzy AHP and COPRAS methodology. SocioEconomic Planning Sciences, 46(3), 230-241.

Davis, F.D. (1989). Perceived usefulness, Perceived ease of use, and user acceptance of Information Technology.

Ekwueme, C. O. (2007). Assessment of Teachers' level of literacy and attitude. International Journal of Emerging Technology and Advanced Engineering.2250-2459, volume 3, Issue 11.

Evoh, C. (2007). Policy networks and the transformation of secondary education through ICTs in Africa: The prospects and challenges of the NEPAD e-Schools initiative. International Journal of Education and Development using ICT, 3(1), 64-84.
Kamal, M., \& Qureshi, S. (2009). How can information and communication technology bring about development? An information architecture for guiding interventions in developing regions.

Kombo, K. and Tromp, L.A. (2006). Proposal and Thesis Writing. An Introduction.

Kothari, C.R. (2004). Research methodology. Methods and techniques (2nd revised ed)

MINECOFIN (2007c) National Guide for Planning, Budgeting and Policy Review, Republic of Rwanda, Kigali.

MINECOFIN, J. (2007). The Economic Development and Poverty Reduction Strategy (EDPRS). Final Draft. Kigali.

Ministry of Education, Kenya (2012). ICT integration in education, Ministry of Education. Nairobi. Government Printers.

Mugenda, O.M \& Mugenda, A.G (2003) Research Methods: Quantitative and Qualitative Approaches Nairobi: ACTS Press.

Oulo I. O. (2013). Preparedness of the Headteachers in the Use of Information Communication Technology in Public Primary Schools in Bondo District, Kenya. Unpublished Research Report of the University of Nairobi.

Sabzian, F., Gilakjani, A. P., \& Sodouri, S. (2013). Use of technology in classroom for professional development. Journal of Language Teaching and Research, 4(4), 684.

World Bank, (1995). Applying New Technologies and Cost-Effective Delivery Systems in Basic Education. World Economic Forum, Dakar.

World Bank. 2002. Globalization, growth, and poverty: building an inclusive world economy. A World Bank policy research report. Washington, D.C. The World Bank. 